\title{
Growth, Phenology and Yield of Basmati Rice as Influenced by Modes of Production and Cropping Systems in Mollisols
}

\author{
Gangadhar Nanda*, D.K. Singh, Subhash Chandra, P.C. Pandey, \\ Shilpi Gupta and Yogesh Sharma
}

\author{
Department of Agronomy, G. B. Pant University of Agriculture and Technology, Pantnagar, \\ Uttarakhand - 263 145, India \\ *Corresponding author
}

\section{A B S T R A C T}

\section{Keywords \\ Growth, Phenology, \\ Yield, Basmati rice, \\ Cropping systems \\ Article Info \\ Accepted: \\ 06 August 2018 \\ Available Online: \\ 10 September 2018}

\begin{abstract}
Field experiments were laid out in split-plot design with three modes of production (organic, integrated and inorganic) in main plots and four rice-based cropping systems [basmati rice-vegetable pea + coriander $\left(\mathrm{CS}_{1}\right)$, basmati rice-chickpea + coriander $\left(\mathrm{CS}_{2}\right)$, basmati rice-potato $\left(\mathrm{CS}_{3}\right)$ and basmati rice-wheat $\left.\left(\mathrm{CS}_{4}\right)\right]$ in sub-plots with three replications in 2016 and 2017. Results revealed that organic mode of production resulted in higher growth and yield of basmati rice than inorganic mode of production during $13^{\text {th }}$ and $14^{\text {th }}$ year of the experimentation. Similarly, legume based cropping systems (basmati rice-chickpea + coriander and/or basmati rice-vegetable pea + coriander) improved the growth and yield of basmati rice.
\end{abstract}

\section{Introduction}

In India, post-independence agriculture has witnessed several undesirable consequences in the want to produce more and more to feed hungry population. Often these are called as ill effects of green revolution. Few examples of these are; indiscriminate use of natural resources, imbalance fertilization with no or little emphasis on organics, over emphasis on use of synthetic chemicals etc. In due course, these became parts of conventional practice of farming. Pollution of environment (Horrigan et al., 2002), reduction in bio-diversity (Lupwayi et al., 2001; Oehl et al., 2004) and soil erosion (Reganold et al., 1987) are some of the most important negative impacts of conventional farming, which are paid much attention these days due to environmental and public health concerns (Horrigan et al., 2002). The long-term sustainability of conventional crop production practices has become questionable due to these negative impacts. Thus to sustain the production system in long run "devoid of unsustainable components of conventional farming" scope of integrated farming in general and organic farming in particular has received increasing attention. "Organic agriculture/farming may encompass any food production system which minimizes the flow of inputs and outputs, sequesters nonrenewable resources, while maintaining, if not increasing, the internal flows of energy, mass and nutrients within the natural boundaries of 
that system" (Jaradat, 2015). Organic farming methods depend on organic inputs and their recycling for nutrient supply, crop rotation and biological methods of pest control and avoid the use of synthetic fertilizers and pesticides (Rigby and Cáceres, 2001).

According to Kundu et al., (2010), even application of chemical fertilizers in balanced amounts cannot sustain the productivity and soil fertility in different continuous cropping systems because agriculture is experiencing a lot of stresses now-a-days. Emphasizing combined application of organic and inorganic sources called integrated nutrient management which is the application of appropriate combination of different sources of plant nutrients as per the location-specific availability for attaining maximum economic yield without impairing the physical, chemical and biological properties of the soil.

Rice-wheat system is the predominant cropping system among rice-based cropping system which occupies $10.5 \mathrm{mha}$ in the IGPs of India. This cereal-cereal cropping system has resulted in pollution of underground water, decline in soil health, and now showing yield stagnation which crop diversification with legumes and vegetable crop to get higher yield and income. Inclusion of legumes involves lower cost and results in saving nitrogen fertilizer. Also, preceding legume crop has marked effect on succeeding cereal crop in terms of better growth and yield. Out of different types of rice being in cultivation, basmati rice fetches high market price due to its better organoleptic quality character and also its demand is high in foreign market (Singh et al., 2017). Chickpea, potato, vegetable pea, lentil, coriander etc. are the promising rabi/spring season crops of the Northern India. Hence, the present experiment was conducted to test the effect of different modes of production and cropping systems on growth, phenology and yield of basmati rice.

\section{Materials and Methods}

The present experiment was laid out in split plot design keeping mode of production (organic, inorganic and integrated) in main plots and different basmati rice-based cropping systems in sub-plots with three replications. The present study commenced in 2004-05. Till 2013, basmati rice-vegetable pea, basmati rice-lentil, basmati rice-Brassica napus and basmati rice-wheat were followed. From 2013, basmati rice-vegetable pea + coriander, basmati rice-chickpea + coriander, basmati rice-potato crop rotations replaced the previous systems, respectively The current investigation was carried out during $13^{\text {th }}$ and $14^{\text {th }}$ year of the experimentation.. The chemical analysis of the soil samples before initiation of the experiment (2004-05) revealed that it was neutral in reaction (7.4), medium in organic carbon $(0.65 \%)$, low in available nitrogen $(238 \mathrm{~kg} / \mathrm{ha})$, medium in available phosphorus and potassium (16.7 and $238 \mathrm{~kg} / \mathrm{ha}$, respectively).

In organic mode of production, incorporation of in-situ green manure crop of Sesbania aculteata (cv. Pant Ses-1) (55 days after sowing) + application of $25 \mathrm{~kg} \mathrm{~N} / \mathrm{ha}$ through vermicompost (VC) at 20-25 DAT was done. In integrated mode of production, $50 \%$ recommended dose of fertilizer (RDF) + incorporation of in-situ green manure crop of Sesbania aculteata (40 days after sowing) was done. In inorganic mode of production, recommended dose of fertilizer (RDF) for basmati rice i.e. 120:60:40 N, $\mathrm{P}_{2} \mathrm{O}_{5}$ and $\mathrm{K}_{2} \mathrm{O} /$ ha was applied. Of this, $50 \% \mathrm{~N}+$ full $\mathrm{P}_{2} \mathrm{O}_{5}$ and $\mathrm{K}_{2} \mathrm{O}$ were applied as basal and rest $50 \% \mathrm{~N}$ was applied in two equal splits each at active tillering (20-25 DAT) and panicle initiation (45-50 DAT) stages. The sources of chemical fertilizers were NPK mixture, urea and MOP. Foliar spray of zinc sulphate @ $0.5 \%$ was done in 2016 for correction of $\mathrm{Zn}$ deficiency in organic mode. Weed 
management in organic mode of production was done manually (20 and 40 DAT) and for integrated and inorganic modes were done using herbicides (Butachlor @ 1 kg a.i./ha and Bispyribac sodium@0.20 kg a.i./ha as preand post-emergence application). Seeds of green manure crop were sown on $25^{\text {th }}$ April in both the years. Four week old basmati rice seedlings (cv. Pant Basmati-1) were transplanted in puddled fields at $25 \times 12.5 \mathrm{~cm}$ spacing on June 29, 2016 and July 1, 2017 for the studied years. To control the insects mainly stem borer, Trichocards (1 card per acre area; 5 releases), pheromone traps (20 traps/ ha at $20 \times 25 \mathrm{~m}$ distance) and cow urine (10\%) mixed with neem oil @ $125 \mathrm{~mL} / \mathrm{L}$ were used after 15 days of transplanting and 45 sprays were done at 15 days interval. To control the diseases, seed treatment, soil and foliar application of Trichoderma spp. and Pseudomonas spp. were done. Observations were recorded on growth attributes were the average of sixteen hills. For phonological studies, the marked sixteen hills were used. The emergence of panicles from the marked hills was examined regularly on alternate days to ascertain the date of flowering. When anthers will protrude out of glumes in more than 50 per cent of panicles, the date was considered as the attainment of 50 per cent flowering from the transplanting date and the number of days from the date of transplanting was noted. Similarly, for days to maturity, the selected hills were monitored visually at two days interval till these start to turn yellow. When 90 per cent of the grain-glumes in selected panicles turned light-brown (straw) or bronze coloured and did not have any greenish tinge at the lower end, the data were treated as maturity.

The complete maturity of the crop was determined by testing the toughness/hardness of grain by cutting it with teeth. Grain yield was recorded from the net plot and was expressed at $14 \%$ moisture. The data obtained were subjected to analysis of variance as per split plot design (Gomez and Gomez, 1984),

\section{Results and Discussion}

\section{Growth attributes}

During both the years of study, the plant height progressively increased as the crop age advanced (Table 1). The increase in plant height was the maximum between 30 to 60 days after transplanting (DAT). Except at harvest 2016, the plant differed significantly among production modes. At all the stages, plant height was the highest under organic mode of cultivation, and did not differ significantly with integrated mode of production. During both the years at 30 DAT, integrated mode also recorded significantly higher plant height than inorganic mode. The tiller production increased up to 60 DAT during both the years and decreased thereafter at 90 DAT, the highest tillers were noted under organic mode of production, which were at par with the integrated mode of production except $30 \& 90$ DAT in 2017 and 60 and 90 DAT in 2016 (Table 5). Under inorganic mode, the tiller number was the lowest at all the stages of determinations. It did not differ significantly with integrated mode of production at 60 DAT in 2016 and 90 DAT during both the years. Invariably, the order of the tiller production was organic > integrated $>$ inorganic system. Nutrient release from green manure starts within a week of its incorporation (Balasubramaniyan and Palaniappan, 1992). So, that might have supplied sufficient quantity of nutrients continuously during the earlier stage to rice crop. Further, the application of vermicompost at active tillering stage might have further prolonged the availability of nitrogen even during the critical stages of rice crop. Better physical properties in organic mode possibly promoted higher root growth which exploited the greater volume of soil as compared to the 
other two modes of production. Addition of greater quantity of different organic manures over the years resulted in build-up of soil organic carbon which might have nurtured microbial communities responsible for plant growth promotion through rhizosperic activities resulting in higher growth attributes of basmati rice like plant height and number of tillers $\mathrm{m}^{-2}$.

The plant height of basmati rice was affected significantly due to cropping systems at 30 and 60 DAT during both the years (Table 1). The plant height did not differ significantly among $\mathrm{CS}_{1}, \mathrm{CS}_{2}$ and $\mathrm{CS}_{3}$. The highest plant height was noticed after chickpea + coriander intercropping. At all the stages of observations, the lowest plant height was found following wheat crop $\left(\mathrm{CS}_{4}\right)$. Cropping systems brought significant difference in tiller production at all the stages except 30 DAT in 2017. At all the stages, the maximum tiller number $\mathrm{m}^{-2}$ was found in $\mathrm{CS}_{2}$ (Table 5). It was significantly the highest at 60 and 90 DAT in 2016, at remaining stages, it remained at par with $\mathrm{CS}_{1}$. The order of the tiller production remained consistent across the stages and followed the order $\mathrm{CS}_{2}>\mathrm{CS}_{1}>\mathrm{CS}_{3}>\mathrm{CS}_{4}$. Higher growth attributes like plant height and number of tillers $\mathrm{m}^{-2}$ of basmati rice were observed either in basmati rice-vegetable pea + coriander $\left(\mathrm{CS}_{1}\right)$ or basmati rice-chickpea + coriander $\left(\mathrm{CS}_{2}\right)$ cropping system where legumes were included. This might be due to nitrogen contribution from the preceding legume crop. Sharma and Jain (2014) observed also observed considerable effect of preceding legume crop (groundnut) on cereal crop (wheat) in terms of improved plant height and number of tillers $\mathrm{m}^{-2}$.

The interaction effects were found significant on plant height of basmati rice at 30 DAT in 2016 (Table 2) and 60 DAT during both the years (Table 3 and 4). At 30 DAT (2016), the highest plant height was recorded in $\mathrm{CS}_{1}$ under organic mode of production $(67.9 \mathrm{~cm})$, which did not differ significantly in $\mathrm{CS}_{2}$ under organic mode $(65.4 \mathrm{~cm})$ and in $\mathrm{CS}_{3}$ under integrated mode $(64.6 \mathrm{~cm})$. At 60 DAT (2016), the highest plant height was noted in $\mathrm{CS}_{2}$ under organic mode $(107.5 \mathrm{~cm})$, which remained at par with $\mathrm{CS}_{1}$ both under organic $(103.2 \mathrm{~cm})$ and integrated mode $(103.8 \mathrm{~cm})$. At 60 DAT (2017), the maximum plant height $(110.2 \mathrm{~cm})$ was found in $\mathrm{CS}_{2}$ under organic mode, and it did not differ significantly with $\mathrm{CS}_{1}$ both under organic $(105.5 \mathrm{~cm})$ and integrated modes of production $(105.8 \mathrm{~cm})$. The interaction of the modes of production and cropping system was found significant at 30 (Table 6) and 60 DAT (Table 7) in 2016 for number of tillers $\mathrm{m}^{-2}$.

At 30 DAT (2016), the tiller number did not vary significantly among $\mathrm{CS}_{1}, \mathrm{CS}_{3}$ and $\mathrm{CS}_{4}$ under organic mode and $\mathrm{CS}_{2}$ under integrated mode of production. In all the cropping systems, significantly the lowest values of tiller number were found under inorganic mode of production. Under inorganic mode of production, $\mathrm{CS}_{2}$ recorded significantly higher number of tillers $\left(152 \mathrm{~m}^{-2}\right)$ than $\mathrm{CS}_{4}\left(130 \mathrm{~m}^{-2}\right)$. At 60 DAT (2016), $\mathrm{CS}_{2}$ recorded significantly the highest number of tillers $\left(349 \mathrm{~m}^{-2}\right)$.

Among remaining treatment combinations, the tiller number did not vary significantly among $\mathrm{CS}_{1}\left(318 \mathrm{~m}^{-2}\right), \mathrm{CS}_{4}\left(313 \mathrm{~m}^{-2}\right)$ under organic mode and $\mathrm{CS}_{3}\left(318 \mathrm{~m}^{-2}\right)$ under integrated mode of production. In $\mathrm{CS}_{1}$ and $\mathrm{CS}_{3}$, under inorganic mode, the tiller number did not vary significantly with integrated mode. Better growth attributes of basmati rice (plant height and number of tillers $\mathrm{m}^{-2}$ ) due to of legume included cropping systems $\left(\mathrm{CS}_{2}\right.$ and $\left.\mathrm{CS}_{1}\right)$ might be due to better improved nitrogen availability and micro-nutrient status with organic mode than integrated and inorganic mode. 
Table.1 Effect of different modes of production and cropping systems on plant height at different stages of basmati rice

\begin{tabular}{|c|c|c|c|c|c|c|c|c|}
\hline & \multicolumn{2}{|c|}{$30 \mathrm{DAT}$} & \multicolumn{2}{|c|}{$60 \mathrm{DAT}$} & \multicolumn{2}{|c|}{$90 \mathrm{DAT}$} & \multicolumn{2}{|c|}{ Harvest } \\
\hline & 2016 & 2017 & 2016 & 2017 & 2016 & 2017 & 2016 & 2017 \\
\hline \multicolumn{9}{|c|}{ Modes of production } \\
\hline Organic & 64.7 & 61.0 & 103.7 & 106.0 & 123.7 & 125.6 & 134.5 & 135.7 \\
\hline Integrated & 62.4 & 59.4 & 99.2 & 101.1 & 122.3 & 124.2 & 133.5 & 133.9 \\
\hline Inorganic & 51.1 & 48.9 & 93.5 & 96.0 & 119.3 & 120.7 & 132.3 & 131.6 \\
\hline SEm \pm & 1.1 & 1.3 & 1.7 & 1.4 & 0.8 & 0.7 & 0.5 & 0.4 \\
\hline $\mathrm{CD}(P=0.05)$ & 4.2 & 5.2 & 6.6 & 5.7 & 3.1 & 2.6 & NS & 1.7 \\
\hline \multicolumn{9}{|c|}{ Cropping systems } \\
\hline $\mathrm{CS}_{1}$ & 60.4 & 57.4 & 99.8 & 101.6 & 123.3 & 124.7 & 134.4 & 134.7 \\
\hline $\mathbf{C S}_{2}$ & 61.3 & 59.2 & 100.2 & 103.1 & 123.1 & 125.1 & 133.2 & 135.6 \\
\hline $\mathrm{CS}_{\mathbf{3}}$ & 59.3 & 55.4 & 99.0 & 101.1 & 120.8 & 123.5 & 132.8 & 132.4 \\
\hline $\mathrm{CS}_{4}$ & 56.7 & 53.7 & 96.2 & 98.3 & 119.9 & 120.6 & 133.1 & 132.3 \\
\hline SEm \pm & 0.7 & 0.8 & 0.9 & 1.0 & 1.4 & 1.3 & 1.0 & 1.0 \\
\hline $\mathrm{CD}(P=0.05)$ & 2.1 & 2.3 & 2.6 & 3.0 & NS & NS & NS & NS \\
\hline $\mathrm{MP} \times \mathrm{CS}$ & $\mathrm{S}$ & NS & $\mathrm{S}$ & $\mathrm{S}$ & NS & NS & NS & NS \\
\hline
\end{tabular}

Table.2 Interaction effect of different modes of production and cropping systems on plant height of basmati rice at 30 DAT during 2016

\section{Modes of production}

\section{Organic}

Integrated

Inorganic

SEm \pm

\begin{tabular}{|c|c|c|c|}
\hline \multicolumn{4}{|c|}{ Cropping systems } \\
\hline $\mathrm{CS}_{1}$ & $\mathrm{CS}_{2}$ & $\mathrm{CS}_{3}$ & $\mathrm{CS}_{4}$ \\
\hline 67.9 & 65.4 & 63.5 & 62.1 \\
\hline 60.8 & 63.9 & 64.6 & 60.2 \\
\hline 52.4 & 54.6 & 49.7 & 47.9 \\
\hline 1.2 & $\mathrm{CD}(P=0.05)$ & 3.5 & \\
\hline
\end{tabular}

Table.3 Interaction effect of different modes of production and cropping systems on plant height of basmati rice at 60 DAT during 2016

\begin{tabular}{|l|c|c|c|c|}
\hline \multirow{2}{*}{ Modes of production } & \multicolumn{4}{|c|}{ Cropping systems } \\
\cline { 2 - 5 } & $\mathrm{CS}_{1}$ & $\mathrm{CS}_{2}$ & $\mathrm{CS}_{3}$ & $\mathrm{CS}_{4}$ \\
\hline Organic & 103.2 & 107.5 & 101.6 & 102.4 \\
\hline Integrated & 103.8 & 99.3 & 100.3 & 93.2 \\
\hline Inorganic & 92.5 & 93.8 & 95.0 & 92.9 \\
\hline SEm \pm & 1.5 & $\mathrm{CD}(P=0.05)$ & 4.5 & \\
\hline
\end{tabular}


Table.4 Interaction effect of different modes of production and cropping systems on plant height of basmati rice at 60 DAT during 2017

\begin{tabular}{|l|c|c|c|c|}
\hline \multirow{2}{*}{ Modes of production } & \multicolumn{4}{|c|}{ Cropping systems } \\
\cline { 2 - 5 } & $\mathrm{CS}_{1}$ & $\mathrm{CS}_{2}$ & $\mathrm{CS}_{3}$ & $\mathrm{CS}_{4}$ \\
\hline Organic & 105.5 & 110.1 & 104.0 & 104.4 \\
\hline Integrated & 105.8 & 102.0 & 101.7 & 94.8 \\
\hline Inorganic & 93.5 & 97.1 & 97.7 & 95.6 \\
\hline SEmm \pm & 1.8 & $\mathrm{CD}(P=0.05)$ & 5.2 & \\
\hline
\end{tabular}

Table.5 Effect of different modes of production and cropping systems on number of tillers $\mathrm{m}^{-2}$ at different stages of basmati rice

\begin{tabular}{|c|c|c|c|c|c|c|}
\hline & \multicolumn{2}{|c|}{ 30 DAT } & \multicolumn{2}{|c|}{$60 \mathrm{DAT}$} & \multicolumn{2}{|c|}{90 DAT } \\
\hline & 2016 & 2017 & 2016 & 2017 & 2016 & 2017 \\
\hline \multicolumn{7}{|c|}{ Modes of production } \\
\hline Organic & 247 & 253 & 314 & 308 & 289 & 285 \\
\hline Integrated & 222 & 227 & 287 & 290 & 273 & 270 \\
\hline Inorganic & 140 & 144 & 270 & 266 & 266 & 259 \\
\hline$\overline{\text { SEm } \pm}$ & 7 & 8 & 6 & 6 & 4 & 4 \\
\hline $\mathrm{CD}(P=0.05)$ & 26 & 31 & 23 & 25 & 16 & 15 \\
\hline \multicolumn{7}{|c|}{ Cropping systems } \\
\hline $\mathbf{C S}_{1}$ & 208 & 214 & 291 & 293 & 279 & 274 \\
\hline $\mathrm{CS}_{2}$ & 209 & 216 & 309 & 301 & 298 & 281 \\
\hline $\mathrm{CS}_{\mathbf{3}}$ & 205 & 210 & 285 & 281 & 268 & 267 \\
\hline $\mathbf{C S}_{4}$ & 188 & 192 & 276 & 277 & 260 & 264 \\
\hline SEm \pm & 3 & 6 & 3 & 6 & 4 & 4 \\
\hline $\mathrm{CD}(P=0.05)$ & 10 & NS & 8 & 18 & 13 & 12 \\
\hline $\mathrm{MP} \times \mathbf{C S}$ & $S$ & NS & S & NS & NS & NS \\
\hline
\end{tabular}

Table.6 Interaction effect of different mode of production and cropping system on number of tillers $\mathrm{m}^{-2}$ of basmati rice at 30 DAT during 2016

\begin{tabular}{|l|c|c|c|c|}
\hline \multirow{2}{*}{ Modes of production } & \multicolumn{4}{|c|}{ Cropping systems } \\
& $\mathrm{CS}_{1}$ & $\mathrm{CS}_{2}$ & $\mathrm{CS}_{3}$ & $\mathrm{CS}_{4}$ \\
\hline Organic & 252 & 236 & 257 & 241 \\
\hline Integrated & 239 & 240 & 216 & 192 \\
\hline Inorganic & 135 & 152 & 141 & 130 \\
\hline SEm \pm & 6 & $\mathrm{CD}(P=0.05)$ & 18 & \\
\hline
\end{tabular}


Table.7 Interaction effect of different mode of production and cropping system on number of tillers $\mathrm{m}^{-2}$ of basmati rice at 60 DAT during 2016

\begin{tabular}{|l|c|c|c|c|}
\hline \multirow{2}{*}{ Modes of production } & \multicolumn{4}{|c|}{ Cropping systems } \\
\cline { 2 - 5 } & $\mathrm{CS}_{1}$ & $\mathrm{CS}_{2}$ & $\mathrm{CS}_{3}$ & $\mathrm{CS}_{4}$ \\
\hline Organic & 318 & 349 & 276 & 313 \\
\hline Integrated & 291 & 277 & 318 & 261 \\
\hline Inorganic & 264 & 300 & 262 & 253 \\
\hline SEm & 5 & $\mathrm{CD}(P=0.05)$ & 14 & \\
\hline
\end{tabular}

Table.8 Effect of different modes of production and cropping systems on phenology and grain yield of basmati rice

\begin{tabular}{|c|c|c|c|c|c|c|}
\hline & \multicolumn{2}{|c|}{$\begin{array}{c}\text { Days to } 50 \% \\
\text { flowering (DAT) }\end{array}$} & \multicolumn{2}{|c|}{$\begin{array}{c}\text { Days to maturity } \\
\text { (DAT) }\end{array}$} & \multicolumn{2}{|c|}{ Grain yield } \\
\hline & 2016 & 2017 & 2016 & 2017 & 2016 & 2017 \\
\hline \multicolumn{7}{|c|}{ Modes of production } \\
\hline Organic & 68 & 72 & 97 & 102 & 4973 & 4976 \\
\hline Integrated & 69 & 73 & 97 & 102 & 4302 & 4858 \\
\hline Inorganic & 72 & 76 & 101 & 105 & 3769 & 4212 \\
\hline SEm & 0 & 0 & 0 & 0 & 79 & 63 \\
\hline $\mathrm{CD}(P=0.05)$ & 2 & 2 & 2 & 2 & 309 & 249 \\
\hline \multicolumn{7}{|c|}{ Cropping systems } \\
\hline $\mathrm{CS}_{1}$ & 69 & 73 & 98 & 102 & 4588 & 4773 \\
\hline $\mathbf{C S}_{2}$ & 69 & 73 & 98 & 103 & 4608 & 4899 \\
\hline $\mathrm{CS}_{\mathbf{3}}$ & 70 & 74 & 98 & 103 & 4298 & 4565 \\
\hline $\mathrm{CS}_{4}$ & 71 & 75 & 99 & 104 & 3899 & 4491 \\
\hline SEm \pm & 0 & 0 & 0 & 0 & 63 & 53 \\
\hline $\mathrm{CD}(P=0.05)$ & NS & NS & NS & NS & 188 & 157 \\
\hline $\mathrm{MP} \times \mathrm{CS}$ & NS & NS & NS & NS & $\mathrm{S}$ & NS \\
\hline
\end{tabular}

* DAT- Days after transplanting

Table.9 Interaction effect of modes of production and cropping system on grain yield of basmati rice during 2016

\begin{tabular}{|l|c|c|c|c|}
\hline \multirow{2}{*}{ Modes of production } & \multicolumn{4}{|c|}{ Cropping systems } \\
\cline { 2 - 5 } & $\mathrm{CS}_{1}$ & $\mathrm{CS}_{2}$ & $\mathrm{CS}_{3}$ & $\mathrm{CS}_{4}$ \\
\hline Organic & 5088 & 5446 & 4786 & 4574 \\
\hline Integrated & 4702 & 4146 & 4853 & 3508 \\
\hline Inorganic & 3974 & 4233 & 3256 & 3616 \\
\hline SEm & 110 & $\mathrm{CD}(P=0.05)$ & 326 & \\
\hline
\end{tabular}




\section{Phenology}

Different modes of production caused significant variation in days to $50 \%$ flowering and days to maturity of basmati rice (Table 8). During both the years, organic mode of production took least days to $50 \%$ flowering (68 and 72 days), being at par with integrated mode (69 and 73 days) during both years. However, both of them were significantly lower than inorganic mode of production (72 and 76 days). The days to maturity were same for organic and inorganic in the years (97 and 102 days) which were significantly lower than inorganic mode. Balanced supply of both macro and micronutrient in long-term organic mode of production lowered the number of days taken to $50 \%$ flowering than integrated and inorganic mode. Faster vegetative growth in organic and integrated mode of production might be the reason for attainment of maturity earlier than inorganic mode of production.

The variation in days to $50 \%$ flowering and days to maturity were insignificant during 2016 and 2017 (Table 8). Basmati rice after chickpea + coriander and vegetable pea + coriander took lesser days to $50 \%$ flowering (69 and 73 days each, respectively) than after potato and wheat during 2016 and 2017. Basmati rice after chickpea + coriander, vegetable pea + coriander and potato took lesser days to maturity (98 days each) than after wheat (99 days) during 2016. During 2017, basmati rice after vegetable pea + coriander took lesser days to maturity (102 days) than after wheat (104 days).

\section{Grain yield}

Different modes of production had significant effect on grain yield during both the years (Table 8). The maximum grain yields were recorded with organic mode (4973 and 4976 $\mathrm{kg} / \mathrm{ha}$, respectively) which was significantly higher than both integrated and inorganic modes of production except for integrated mode in 2017 where it recorded at par grain yield with organic mode. The increments in grain yields with organic mode over integrated and inorganic modes during 2016 and 2017 were $15.59 \%$ and $31.94 \%$ and 2.43 $\%$ and $18.13 \%$, respectively. Use of in-situ sesbania green manure and application of vermicompost to the rice crop and vermicompost and farm yard manure to $r a b i$ crops for several years maintained higher organic matter in soil and thereby sustained soil health and ultimately the productivity of rice. The increase in grain yield with organic mode of production might also be due to slow releasing nature of nutrients from organic manures over a longer time span increasing the availability of ammonia and nitrate form of nitrogen (Chettri et al., 1988) and increased efficiency of native and applied phosphorus due to secretion of organic acids during the decomposition of organic manures (Narwal and Choudhary, 2006; Backiyavathy and Vijayakumar, 2006) and increased water holding capacity of soil (Banik et al., 2006). Similar findings have been reported for basmati rice (Singh et al., 2012; Singh et al., 2017).

Preceding rabi crops had marked effect on grain yield of basmati rice during 2016 and 2017 (Table 8). The maximum grain yield was obtained with $\mathrm{CS}_{2}$ (4608 and $4899 \mathrm{~kg} / \mathrm{ha}$, respectively) followed by $\mathrm{CS}_{1}$ (4588 and 4773 $\mathrm{kg} / \mathrm{ha}$, respectively) and the minimum grain yield was obtained after wheat (3899 and $4491 \mathrm{~kg} / \mathrm{ha}$, respectively) i.e. in $\mathrm{CS}_{4}$ during both the years. The increment in grain yield with chickpea + coriander as preceding crop $\left(\mathrm{CS}_{2}\right)$ as compared to wheat $\left(\mathrm{CS}_{4}\right)$ for 2016 and 2017 was 18.18 and $9.04 \%$, respectively. The grain yield of succeeding crop increases markedly when legume is taken as preceding crop than when a cereal crop is taken as preceding crop. But the magnitude of yield 
increment depends upon the amount of nitrogen left by the legume crop for succeeding cereal crop (Ghosh et al., 2007). Continuous cereal-cereal cropping system is known to deplete soil fertility. Higher grain yield with $\mathrm{CS}_{2}$ and $\mathrm{CS}_{1}$ is attributed to the improvement is soil fertility especially with respect to available $\mathrm{N}$ due to atmospheric nitrogen fixation which was helpful in enhancing the yield of succeeding rice crop as compared to cereal as preceding crop (wheat).

The interaction effect of modes of production and cropping systems was found significant during 2016 (Table 9). The highest grain yield of basmati rice was recorded with organic mode in $\mathrm{CS}_{2}(5446 \mathrm{~kg} / \mathrm{ha})$ which was significantly higher than other combination of modes of production and cropping systems. This might be attributed to higher nitrogen status with this combination of mode of production and cropping system than that of other combination.

Based on the findings of present investigation, it is concluded that in long run, organic mode of production resulted in higher growth and yield of basmati rice than inorganic mode of production. Legume based cropping systems (basmati rice-chickpea + coriander and/or basmati rice-vegetable pea + coriander) improved the growth and yield of basmati rice due to higher nitrogen contribution from preceding crop.

\section{References}

Backiyavathy, M. R. and Vijayakumar, G. 2006. Effect of vermicompost, inorganic and biofertilizer application on fodder yield and quality in maize + cowpea intercropping system. $18^{\text {th }}$ World Congress on soil Science in Philadelphia, 2006 from July 9-15, Pennsylvania, USA.
Balasubramaniyan, P. and Palaniappan, S. P. 1992. Studies on the effect of green manuring and $\mathrm{N}$ application in ricemoong cropping system. Ind. J. Agron. 35(3): 297-298.

Banik, P., Ghosh, P. K., Sasmal, T. K., Bhattacharya, S., Sarkar, B. K. and Bagchi, D. K. 2006. Effect of organic and inorganic nutrients for soil quality conservation and yield of rainfed low land rice in sub-tropical plateau region. J. Agron. Crop Sci. 192: 331-343.

Bastia, D. K., Garnayak, L. M. and Barik, T. 2008. Diversification of rice (Oryza sativa)- based cropping systems for higher productivity, resource-use efficiency and economics. Indian Journal of Agronomy 53(1): 22-26.

Chhetri, G. B., Rai, B. B. and Samiano, A. R. 1988. Effects at FYM supplement with $\mathrm{N}, \mathrm{P}$ and $\mathrm{K}$ on grain yield of rice. International Rice Research Newsletter 13: $17-28$.

Ghosh, P. K., Bandyopadhyay, K. K., Wanjari, R. H., Manna, M. C., Misra, A. K., Mohanty, M. and Rao, A. S. 2007. Legume effect for enhancing productivity and nutrient use-efficiency in major cropping systems-an Indian perspective: a review. Journal of Sustainable Agriculture: 30(1): 59-86.

Gomez, K. A. and Gomez, A. A. 1984. Statistical procedures for agricultural research, Second edition, John and Wiley Sons, New York.

Horrigan, L., Lawrence, R. S. and Walker, P. 2002. How sustainable agriculture can address the environmental and human health harms of industrial agriculture. Environ. Health Persp. 110: 445-456.

Jaradat, A. A. 2015. Organic agriculture: The science and practices under a changing climate. Emirates Journal of Food and Agriculture 27(5): 1-2.

Kundu, K., Brahmachari, K. and Karmakar, S. 2010. Impact of different organic 
manures in enhancing the growth and productivity of rice (Oryza sativa L.) under coastal saline tract of West Bengal. J. Crop Weed 6 (2): 42-45.

Lupwayi, N. Z., Monreal, M. A., Clayton, G. W., Grant, C. A., Johnston, A. M. and Rice, W. A. 2001. Soil microbial biomass and diversity respond to tillage and sulphur fertilizers. Can. J. Soil Sci. 81: 577-589.

Narwal, R. P. and Chaudhary, M. 2006. Effect of long-term application of FYM and fertilizer $\mathrm{N}$ on available $\mathrm{N}, \mathrm{P}, \mathrm{K}$ and $\mathrm{S}$ content of soil. $18^{\text {th }}$ World Congress on soil Science in Philadelphia, 2006 from July 9-15, Pennsylvania, USA.

Oehl, F., Sieverding, E., Mäder, P., Dubois, D., Ineichen, K., Boller, T. and Wiemken, A. 2004. Impact of long-term conventional and organic farming on the diversity of arbuscular mycorrhizal fungi. Oecologia 138: 574-583.

Reganold, J. P., Elliott, L. F. and Unger, Y. L. 1987. Long-term effects of organic and conventional farming on soil erosion. Nature 330: 370-372.

Rigby, D. and Cáceres, D. 2001. Organic farming and the sustainability of agricultural systems. Agr. Syst. 68: 2140.

Sharma, S. K. and Jain, N. K. 2014. Nutrient management in wheat (Triticum aestivum)-based cropping systems in sub-humid zone of Rajasthan. Indian Journal of Agronomy 59(1): 26-33.

Singh, D. K., Akhtar, Z., Gupta, S., Srivastava A. and Chakraborty, M. 2017a. Production strategies of organic basmati rice in Tarai region of Uttarakhand, India. Organic Agriculture 7(1): 21-30.

Singh, D. K., Singh, G., Gupta, S., Arora, M. and Verma, S. 2012a. Yield sustainability and quality of basmati rice as influenced by conventional, organic and integrated modes of cultivation. Oryza 49(2): 102-107.

\section{How to cite this article:}

Gangadhar Nanda, D.K. Singh, Subhash Chandra, P.C. Pandey, Shilpi Gupta and Yogesh Sharma. 2018. Growth, Phenology and Yield of Basmati Rice as Influenced by Modes of Production and Cropping Systems in Mollisols. Int.J.Curr.Microbiol.App.Sci. 7(09): 675-684. doi: https://doi.org/10.20546/ijcmas.2018.709.080 